\title{
Kaizen methodology for continuous improvement as an entry point to achieve outstanding institutional performance in the Directorate of Youth and Sports in Alexandria Governorate
}

\author{
Assistant Prof. Dr./ Reham Amin Hamza Shehab
}

Assistant Professor, Sports Administration Department, Faculty of Physical Education for Girls, Alexandria University

\section{Research Problem and Importance:}

Current international challenges force organizations to convert from using traditional administrative methods to new methods to exploit human capacities, perhaps (Kaizen) methodology of improving permanent performance is one of the most important new trends suitable for leading organizations for the time being.

Ann Bisou (2016) and Robert Maurer (2012) agreed upon Kaizen as an administrative philosophy and a Japanese strategy aiming at development, permanent improvement (25: 28), (32: 9).

Kai Musashi (2016), Richard Schonberger (2012), Masaaki Imai (2012) define it as creating a slow and permanent change in work via gradual improvement, reducing costs and wastes and increasing productivity. (29: 17), (31: 157), (30: 13).

Benjamin S. Sweet (2015) says that Kaizen's methodology includes a great number of procedures including "adopting Kaizen's methodology by supreme administration, selecting leaderships qualified for applying Kaizen's culture, enhancing teamwork culture, encouraging creative thoughts and reducing wastes". (26: 39).

Charles Protzman (2016) considers method of improvement course or the so called "PDCA" as the most common method of achieving permanent improvement as it consists of four stages: planning, executing, reviewing or examining and finally correction". "Act" (27: 56)

As the researcher, in order to apply Kaizen's methodology, two main factors shall be depended on, the first is the technical one related to reducing waste in operations and improving the operation's time costs and quality, and the second one is related to social aspect while focusing on changing employees and organization's culture.

The researcher could reach the research problem via taking the first place by youth and sports directorate, Alexandria as the level of youth and sports directorates for 2018 / 2019, via contacting some employees in the directorate during executing many activities of civil training curriculum as she observed non availability of all facts for all leaderships to take administrative decisions, and disallowing employees to submit new ideas to carry out improvement operations, some of waste aspects, which made the researcher carry out a pilot study via open interview with (6) persons represented in directorate's manager, directorate's deputy manager and some managers of different departments to know how far are they familiar with permanent improvement concept " Kaizen", as the most important results were "the concept 
of permanent improvement is unclear for all employees, there is no permanent review and revaluation unit".

According to looking into many previous studies results including results of study of Qusayr Bin Odeh (2020) ( 15 ) Moamen Sharafeldin (2012) (1 '), Glover et al. (2011) (28), it was found that main requirements of Kaizen's methodology success are clear policy of desiring improvement and development while study of Nadia Abdelkhalik (2016) (1 T), Twaitia Eltaher (2017) (r3), recommends the necessity of enabling employees to join cultural courses to recognize the importance of using Kaizen's method.

Which made the researcher compile this research titled:

"Kaizen methodology for continuous improvement as an entry point to achieve outstanding institutional performance in the Directorate of Youth and Sports in Alexandria Governorate "

Research Objective:

Identifying effects of using (kaizen) methodology to improve permanent performance of achieve excellent organizational performance at youth and sports directorate in Alexandria through determining:

"The role of supreme administration in improving permanent performance, procedural steps of Kaizen's methodology, and the effect of applying Kaizen's methodology to achieving a distinctive organizational performance related to employees, operations and directorate".

Research Procedures:

Research Method: Survey descriptive method was used as it is suitable for the research nature.

Research Community and Sample:

The research sample included three groups "supreme administration" of (7) persons represented in directorate's manager, directorate's deputy manager, and (5) departments' managers under research, "middle administration" of (8) managers from,

"executive administration" of (69) sports specialist as the whole research sample reached (84) subjects as the pilot sample reached (10) subjects, and (4) forms were set aside due to non data completion; accordingly, the main research sample reached (70) subjects.

\section{Date Collection Tools:}

- Questionnaire form

Form Scientific Coefficients

A- Internal consistence validity of questionnaire form phrases

The researcher used internal consistency method by finding correlation coefficient between phrases and factors they belong to and phrase and the whole questionnaire degree as in tables (1), (2) and (3) 
Table (1) Correlation Coefficient between every Phrase and Dimensions they belong to and the First Factor Degree

$(\mathrm{N}=10)$

\begin{tabular}{|c|c|c|c|c|c|c|c|c|}
\hline \multicolumn{9}{|c|}{ Correlation coefficient of the first factor phrases } \\
\hline Serial & $\begin{array}{l}\text { With the } \\
\text { first factor }\end{array}$ & $\begin{array}{c}\text { With the } \\
\text { whole degree }\end{array}$ & Serial & $\begin{array}{c}\text { With the } \\
\text { first } \\
\text { factor }\end{array}$ & $\begin{array}{c}\text { With the } \\
\text { whole degree }\end{array}$ & Serial & $\begin{array}{l}\text { With the } \\
\text { first factor }\end{array}$ & $\begin{array}{c}\text { With the } \\
\text { whole } \\
\text { degree }\end{array}$ \\
\hline $1 / 1 / 1$ & 0.668 & 0.823 & $1 / 9 / 1$ & 0.756 & 0.767 & $1 / 17$ & 0.693 & 0.761 \\
\hline $1 / 2$ & 0.719 & 0.712 & $1 / 9 / 2$ & 0.731 & 0.783 & $1 / 18$ & 0.718 & 0.748 \\
\hline $1 / 3$ & 0.719 & 0.787 & $1 / 10$ & 0.770 & 0.800 & $1 / 18 / 1$ & 0.787 & 0.874 \\
\hline $1 / 4$ & 0.726 & 0.773 & $1 / 11$ & 0.834 & 0.755 & $1 / 18 / 2$ & 0.792 & 0.765 \\
\hline $1 / 5$ & 0.699 & 0.727 & $1 / 12$ & 0.725 & 0.781 & $1 / 18 / 3$ & 0.767 & 0.745 \\
\hline $1 / 6$ & 0.855 & 0.846 & $1 / 13$ & 0.764 & 0.702 & $1 / 18 / 4$ & 0.765 & 0.748 \\
\hline $1 / 7 / 1$ & 0.731 & 0.765 & $1 / 14$ & 0.771 & 0.754 & $1 / 18 / 5$ & 0.724 & 0.776 \\
\hline $1 / 7 / 2$ & 0.695 & 0.728 & $1 / 15$ & 0.690 & 0.683 & & & \\
\hline $1 / 8$ & 0.773 & 0.761 & $1 / 16$ & 0.697 & 0.681 & & & \\
\hline
\end{tabular}

$\operatorname{Rg}(0.05 .8)=0.632$

Table (2) Correlation Coefficient between every Phrase and Dimensions they belong to and the Second Factor Degree

$(\mathrm{N}=\mathbf{1 0})$

\begin{tabular}{|c|c|c|c|c|c|c|c|}
\hline \multicolumn{4}{|c|}{$\begin{array}{c}\text { Correlation coefficient of the first dimension } \\
\text { phrases }\end{array}$} & \multicolumn{4}{|c|}{ Correlation coefficient of the second dimension phrases } \\
\hline Serial & $\begin{array}{l}\text { With the } \\
\text { first } \\
\text { dimension }\end{array}$ & $\begin{array}{l}\text { With the } \\
\text { second } \\
\text { factor }\end{array}$ & $\begin{array}{c}\text { With the } \\
\text { whole } \\
\text { degree }\end{array}$ & Serial & $\begin{array}{l}\text { With the second } \\
\text { dimension }\end{array}$ & $\begin{array}{l}\text { With the second } \\
\text { factor }\end{array}$ & $\begin{array}{c}\text { With } \\
\text { the } \\
\text { whole } \\
\text { degree }\end{array}$ \\
\hline $2 / 1$ & 0.757 & 0.775 & 0.717 & $3 / 1$ & 0.808 & 0.717 & 0.768 \\
\hline $2 / 2$ & 0.690 & 0.960 & 0.770 & $3 / 2$ & 0.748 & 0.699 & 0.708 \\
\hline $2 / 3$ & 0.757 & 0.964 & 0.717 & $3 / 3$ & 0.875 & 0.817 & 0.835 \\
\hline $2 / 4$ & 0.860 & 0.964 & 0.800 & $3 / 4$ & 0.763 & 0.725 & 0.723 \\
\hline $2 / 5$ & 0.763 & 0.902 & 0.723 & $3 / 5$ & 0.763 & 0.822 & 0.823 \\
\hline $2 / 6$ & 0.737 & 0.710 & 0.697 & $3 / 6$ & 0.808 & 0.790 & 0.768 \\
\hline $2 / 7$ & 0.875 & 0.717 & 0.835 & $3 / 7$ & 0.761 & 0.901 & 0.741 \\
\hline $2 / 8$ & 0.763 & 0.902 & 0.732 & & & & \\
\hline $2 / 9$ & 0.840 & 0.805 & 0.700 & & & & \\
\hline \multicolumn{4}{|c|}{$\begin{array}{l}\text { Correlation coefficient of the third dimension } \\
\text { phrases }\end{array}$} & \multicolumn{4}{|c|}{ Correlation coefficient of the fourth dimension phrases } \\
\hline Serial & $\begin{array}{l}\text { With the } \\
\text { third } \\
\text { dimension }\end{array}$ & $\begin{array}{l}\text { With the } \\
\text { second } \\
\text { factor }\end{array}$ & $\begin{array}{c}\text { With the } \\
\text { whole } \\
\text { degree }\end{array}$ & Serial & $\begin{array}{l}\text { With the fourth } \\
\text { dimension }\end{array}$ & $\begin{array}{l}\text { With the second } \\
\text { factor }\end{array}$ & $\begin{array}{c}\text { With } \\
\text { the } \\
\text { whole } \\
\text { degree }\end{array}$ \\
\hline $4 / 1$ & 0.808 & 0.741 & 0.768 & $5 / 1$ & 0814 & 0.713 & 0.774 \\
\hline $4 / 2$ & 0.711 & 0.827 & 0.771 & $5 / 2$ & 0.773 & 0.750 & 0733 \\
\hline $4 / 3$ & 0.817 & 0.698 & 0.777 & $5 / 3$ & 0.694 & 0.768 & 0.684 \\
\hline $4 / 4$ & 0.774 & 0.788 & 0.734 & $5 / 4$ & 0.817 & 0.822 & 0.857 \\
\hline $4 / 5$ & 0.862 & 0.878 & 0.822 & $5 / 5$ & 0.880 & 0.900 & 0.840 \\
\hline $4 / 6$ & 0.689 & 0.765 & 0.699 & $5 / 6$ & 0.761 & 0.701 & 0.721 \\
\hline $4 / 7$ & 0.849 & 0.899 & 0.809 & & & & \\
\hline
\end{tabular}


$\operatorname{Rg}(0.05 .8)=0.632$

Table (3) Correlation Coefficient between every Phrase and Dimensions they belong to and the Third Factor Degree

$(\mathrm{N}=10)$

\begin{tabular}{|c|c|c|c|c|c|c|c|c|c|c|c|}
\hline \multicolumn{4}{|c|}{$\begin{array}{l}\text { Correlation coefficient of the first } \\
\text { dimension phrases }\end{array}$} & \multicolumn{4}{|c|}{$\begin{array}{l}\text { Correlation coefficient of the second } \\
\text { dimension phrases }\end{array}$} & \multicolumn{4}{|c|}{$\begin{array}{l}\text { Correlation coefficient of the third } \\
\text { dimension phrases }\end{array}$} \\
\hline Serial & $\begin{array}{l}\text { With the } \\
\text { first } \\
\text { dimension }\end{array}$ & $\begin{array}{l}\text { With } \\
\text { the } \\
\text { third } \\
\text { factor }\end{array}$ & $\begin{array}{c}\text { With } \\
\text { the } \\
\text { whole } \\
\text { degree }\end{array}$ & Serial & $\begin{array}{l}\text { With the } \\
\text { second } \\
\text { dimension }\end{array}$ & $\begin{array}{l}\text { With } \\
\text { the } \\
\text { third } \\
\text { factor }\end{array}$ & $\begin{array}{c}\text { With } \\
\text { the } \\
\text { whole } \\
\text { degree }\end{array}$ & Serial & $\begin{array}{l}\text { With the } \\
\text { third } \\
\text { dimension }\end{array}$ & $\begin{array}{l}\text { With } \\
\text { the } \\
\text { third } \\
\text { factor }\end{array}$ & $\begin{array}{c}\text { With } \\
\text { the } \\
\text { whole } \\
\text { degree }\end{array}$ \\
\hline $6 / 1$ & 0.751 & 0.821 & 0.811 & $7 / 1$ & 0.740 & 0.847 & 0.700 & $8 / 1$ & 0.769 & 0.802 & 0.829 \\
\hline $6 / 2$ & 0.442 & 0.756 & 0.702 & $7 / 2$ & 0.901 & 0.760 & 0.861 & $8 / 2 / 1$ & 0.734 & 0.725 & 0.694 \\
\hline $6 / 3$ & 0.833 & 0.823 & 0.793 & $7 / 3 / 1$ & 0.887 & 0.836 & 0.738 & $8 / 2 / 2$ & 0.617 & 0.822 & 0.777 \\
\hline $6 / 4$ & 0.988 & 0.786 & 0.859 & $7 / 3 / 2$ & 0.695 & 0.747 & 0.755 & $8 / 3 / 1$ & 0.742 & 0.698 & 0.802 \\
\hline $6 / 5$ & 0.964 & 0.812 & 0.924 & $7 / 3 / 3$ & 0.737 & 0.714 & 0.697 & $8 / 3 / 2$ & 0.723 & 0.860 & 0.883 \\
\hline $6 / 6$ & 0.817 & 0.822 & 0.777 & $7 / 3 / 4$ & 0.724 & 0.865 & 0.784 & $8 / 3 / 3$ & 0.738 & 0.715 & 0.698 \\
\hline $6 / 7$ & 0.722 & 0.758 & 0.782 & $7 / 4 / 1$ & 0.745 & 0.742 & 0.805 & $8 / 3 / 4$ & 0.695 & 0.767 & 0.755 \\
\hline $6 / 8$ & 0.757 & 0.912 & 0.717 & $7 / 4 / 2$ & 0.719 & 0.865 & 0.779 & $8 / 3$ & 0.698 & 0.691 & 0.758 \\
\hline \multirow[t]{5}{*}{$6 / 9$} & 0.690 & 0.690 & 0.850 & $7 / 4 / 3$ & 0.837 & 0.714 & 0.697 & $8 / 4$ & 0.827 & 0.691 & 0.787 \\
\hline & & & & $7 / 5$ & 0.742 & 0.694 & 0.702 & & & & \\
\hline & & & & $7 / 6$ & 0.775 & 0.749 & 0.735 & & & & \\
\hline & & & & $7 / 7$ & 0.745 & 0.879 & 0.805 & & & & \\
\hline & & & & $7 / 8$ & 0.877 & 0.797 & 0.837 & & & & \\
\hline
\end{tabular}

$\operatorname{Rg}(0.05 .8)=0.632$

It is clear from tables $(1,2,3)$ that there is a statistical significant correlation at significant level $(0.05)$ between degree of every phrases and dimensions belonging to.

\section{Calculating Questionnaire Reliability Coefficient:}

Table (4) Questionnaire Reliability by Split Half and Cronbach's Alpha

\begin{tabular}{|c|c|c|c|}
\hline \multirow[b]{2}{*}{ Factors and Dimensions } & \multicolumn{2}{|c|}{ Split Half } & \multirow[b]{2}{*}{$\begin{array}{c}\text { Cronbach's } \\
\text { Alpha }\end{array}$} \\
\hline & Spearman Brown & Gitman & \\
\hline $\begin{array}{c}\text { First Factor: The role of supreme administration at youth } \\
\text { and sports directorate, in Alexandria in achieving } \\
\text { permanent improvement " Kaizen" }\end{array}$ & 0.731 & 0.719 & 0.811 \\
\hline Second Factor: Kaizen's methodology procedural steps & 0.794 & 0.880 & 0.754 \\
\hline First dimension: Planning & 0.830 & 0.909 & 0.790 \\
\hline Second dimension: Execution & 0.741 & 0.737 & 0.721 \\
\hline Third dimension: Evaluation and Examination & 0.794 & 0.816 & 0.754 \\
\hline Fourth dimension: Responding to suggested improvements & 0.725 & 0.752 & 0.805 \\
\hline $\begin{array}{l}\text { Third Factor: Effect of applying Kaizen's methodology in } \\
\text { achieving distinctive organizational performance at youth } \\
\text { and sports directorate, Alexandria }\end{array}$ & 0.886 & 0.701 & 0.846 \\
\hline $\begin{array}{l}\text { First dimension: Improving performance of employees of } \\
\text { youth and sports directorate }\end{array}$ & 0.840 & 0.801 & 0.830 \\
\hline Second dimension: Improving operations performance & 0.745 & 0.755 & 0.725 \\
\hline $\begin{array}{l}\text { Third dimension: Improving performance of youth and } \\
\text { sports directorate, Alexandria }\end{array}$ & 0.812 & 0.762 & 0.772 \\
\hline
\end{tabular}


It is clear from table (4) that reliability coefficient by split half ranges between (0.701) and (0.909), and Cronbach's Alpha reliability coefficient ranges between (0.721) and (0.846), to prove that the researched questionnaire has a high reliability coefficient.

\section{Statistical Treatment}

"Repetition and percentage, split half, Cronbach's Alpha reliability coefficient, outweighed percentage, Chi square Distribution, Pearson correlation coefficient, out weighted percentages."

\section{Research Results Discussions:}

Table (5) Results of Repetition Percentage, Chi square Distribution and Outweighed Percentage of Response on the First Factor the Role of:

The Role of Supreme Administration at Youth and Sports Directorate in Alexandria Achieving Permanent Improvement "Kaizen"

\begin{tabular}{|c|c|c|c|c|c|c|c|c|c|c|}
\hline \multirow{3}{*}{ Serial } & \multirow{3}{*}{ Phrase content } & \multicolumn{4}{|c|}{$\begin{array}{l}\text { Supreme and middle } \\
\text { administration } \\
\mathrm{N}=12\end{array}$} & \multicolumn{4}{|c|}{$\begin{array}{c}\text { Supreme and middle } \\
\text { administration } \\
\mathbf{N}=\mathbf{5 8}\end{array}$} & \multirow{3}{*}{$\begin{array}{l}\text { Chi Square } \\
\text { Distribution }\end{array}$} \\
\hline & & \multicolumn{2}{|c|}{ Agreeing } & \multicolumn{2}{|c|}{$\begin{array}{c}\text { Disagreein } \\
\mathbf{g} \\
\end{array}$} & \multicolumn{2}{|c|}{ Agreeing } & \multicolumn{2}{|c|}{ Disagreeing } & \\
\hline & & $\mathrm{C}$ & $\%$ & $\mathrm{C}$ & $\%$ & $\mathrm{C}$ & $\%$ & $\mathrm{C}$ & $\%$ & \\
\hline \multicolumn{11}{|l|}{1} \\
\hline $1 / 1$ & $\begin{array}{l}\text { All departments effective } \\
\text { participation in permanent } \\
\text { improvement }\end{array}$ & 10 & 83.33 & 2 & 16.67 & 47 & 81.03 & 11 & 18.97 & 0.035 \\
\hline $1 / 2$ & $\begin{array}{l}\text { Having a business } \\
\text { improvement and } \\
\text { development plan } \\
\text { according to its view, } \\
\text { strategies and objectives }\end{array}$ & 9 & 75.00 & 3 & 25.00 & 23 & 39.66 & 35 & 60.34 & 5.005 \\
\hline $1 / 3$ & $\begin{array}{c}\text { Availing suitable } \\
\text { environmental } \\
\text { circumstances in which } \\
\text { permanent development is } \\
\text { a life style }\end{array}$ & 8 & 66.67 & 4 & 33.33 & 24 & 41.38 & 34 & 58.62 & 2.562 \\
\hline $1 / 4$ & $\begin{array}{c}\text { Allowing a budget for } \\
\text { permanent improvement } \\
\text { operations }\end{array}$ & 5 & 41.68 & 7 & 58.33 & 19 & 32.76 & 39 & 67.24 & 0.350 \\
\hline $1 / 5$ & $\begin{array}{l}\text { Availing substantial and } \\
\text { human potentials to apply } \\
\text { permanent improvement }\end{array}$ & 11 & 91.67 & 1 & 8.33 & 46 & 79.31 & 12 & 20.69 & 1.004 \\
\hline $1 / 6$ & $\begin{array}{c}\text { Graduated application of } \\
\text { permanent improvement of } \\
\text { different operations inside } \\
\text { youth and sports } \\
\text { directorate }\end{array}$ & 11 & 91.67 & 1 & 8.33 & 40 & 68.97 & 18 & 31.03 & 2.591 \\
\hline $1 / 7$ & Holding cultural courses to: & & & & & & & & & \\
\hline $1 / 7 / 1$ & $\begin{array}{l}\text { Know the importance of } \\
\text { using Kaizen method }\end{array}$ & 7 & 58.33 & 5 & 41.67 & 18 & 31.03 & 40 & 68.97 & 3.227 \\
\hline
\end{tabular}




\begin{tabular}{|c|c|c|c|c|c|c|c|c|c|c|}
\hline $1 / 7 / 2$ & $\begin{array}{l}\text { Convincing all employees of } \\
\text { different administrative } \\
\text { levels by all advantages of } \\
\text { applying Kaizen's } \\
\text { methodology }\end{array}$ & 7 & 58.33 & 5 & 41.67 & 12 & 20.69 & 46 & 79.31 & $* 7.125$ \\
\hline $1 / 8$ & $\begin{array}{l}\text { Providing all suppor, } \\
\text { training and education to all } \\
\text { the directorate's employees }\end{array}$ & 10 & 83.33 & 2 & 16.67 & 34 & 58.62 & 24 & 41.38 & 2.601 \\
\hline \multicolumn{11}{|c|}{ 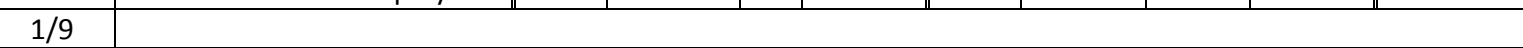 } \\
\hline $1 / 9 / 1$ & $\begin{array}{c}\text { Employees of all the } \\
\text { directorate's administrative } \\
\text { levels }\end{array}$ & 11 & 91.67 & 1 & 8.33 & 45 & 77.59 & 13 & 22.41 & 1.232 \\
\hline $1 / 9 / 2$ & Beneficiaries & 10 & 83.33 & 2 & 16.67 & 49 & 84.48 & 9 & 15.52 & 0.010 \\
\hline $1 / 10$ & $\begin{array}{l}\text { Availing all data and facts of } \\
\text { making administrative } \\
\text { decisions }\end{array}$ & 9 & 75.00 & 3 & 25.00 & 28 & 48.28 & 30 & 51.72 & 2.850 \\
\hline $1 / 11$ & $\begin{array}{l}\text { Availing new evaluation } \\
\text { methods to avoid error } \\
\text { repetition and overcoming } \\
\text { weak points }\end{array}$ & 8 & 66.67 & 4 & 33.33 & 24 & 41.38 & 34 & 58.62 & 2.562 \\
\hline $1 / 12$ & $\begin{array}{c}\text { Motivating all employees } \\
\text { creative efforts }\end{array}$ & 10 & 83.33 & 2 & 16.67 & 32 & 55.17 & 26 & 44.83 & 3.285 \\
\hline $1 / 13$ & $\begin{array}{l}\text { Rewarding the best ideas of } \\
\text { developing the directorate's } \\
\text { work }\end{array}$ & 9 & 75.00 & 3 & 25.00 & 26 & 44.83 & 32 & 55.17 & 3.621 \\
\hline $1 / 14$ & $\begin{array}{l}\text { Making employees' groups } \\
\text { "quality circuits" to solve } \\
\text { problems and obtaining } \\
\text { new ideas }\end{array}$ & 11 & 91.67 & 1 & 8.33 & 52 & 89.66 & 6 & 10.34 & 0.045 \\
\hline $1 / 15$ & $\begin{array}{l}\text { Direct supervision via } \\
\text { visiting the event's site } \\
\text { instead of problems remote } \\
\text { control "Gemba Kaizen" }\end{array}$ & 11 & 91.67 & 1 & 8.33 & 49 & 84.48 & 9 & 15.52 & 0.419 \\
\hline $1 / 16$ & $\begin{array}{l}\text { Taking all sufficient and } \\
\text { immediate preventive } \\
\text { decisions to avoid work } \\
\text { suspension }\end{array}$ & 10 & 83.33 & 2 & 16.67 & 46 & 79.31 & 12 & 20.69 & 0.101 \\
\hline $1 / 17$ & $\begin{array}{c}\text { Discussing employees ideas } \\
\text { at all departments and on a } \\
\text { regular basis to apply the } \\
\text { available ones }\end{array}$ & 10 & 83.33 & 2 & 16.67 & 21 & 36.21 & 37 & 63.79 & $* 8.950$ \\
\hline $1 / 18$ & Employees' participation in: & & & & & & & & & \\
\hline $1 / 18 / 1$ & $\begin{array}{l}\text { selecting the operation } \\
\text { required to be improved }\end{array}$ & 11 & 91.67 & 1 & 8.33 & 32 & 55.17 & 26 & 44.83 & 5.589 \\
\hline $1 / 18 / 2$ & $\begin{array}{l}\text { Looking for new means to } \\
\text { improve the directorate's } \\
\text { operations }\end{array}$ & 11 & 91.67 & 1 & 8.33 & 37 & 63.79 & 21 & 36.21 & 3.584 \\
\hline $1 / 18 / 3$ & $\begin{array}{l}\text { Executing improvement } \\
\text { operations }\end{array}$ & 11 & 91.67 & 1 & 8.33 & 42 & 72.41 & 16 & 27.59 & 2.004 \\
\hline $1 / 18 / 4$ & $\begin{array}{c}\text { Evaluating improvement } \\
\text { operations }\end{array}$ & 8 & 66.67 & 4 & 33.33 & 22 & 37.93 & 36 & 62.07 & 3.352 \\
\hline $1 / 18 / 5$ & $\begin{array}{c}\text { Documenting improvement } \\
\text { operations and informing } \\
\text { them to employees }\end{array}$ & 9 & 75.00 & 3 & 25.00 & 21 & 36.21 & 37 & 63.79 & $* 6.110$ \\
\hline
\end{tabular}

Chi square Distribution (0.05.2) = 5.991 
From table number (5) of the first factor it is clear that there are no significant difference between the research sample groups response about the first factor phrases as Chi square Distribution was less than its value at level (0.05) and ranged between (0.010:5.589) except for phrases number $(1 / 7 / 2,1 / 17,1 / 18 / 5)$

And in case of phrases number $(1 / 7 / 2,1 / 17,1 / 18 / 5)$ it is clear that how far response of research groups subjects differ and as supreme and supervisory administration agreed at percentage ranged from (58.33: $83.33 \%$ ) on that cultural courses are to held to convince all employees of advantages of applying Kaizen's methodology, discussing employees' ideas at every department, we find that executive administration.

Results of study of Rizan Salaheldin, Berzin Sheikh Mohamed (2010) (20) indicates that using Kaizen's method needs the supreme administration support; accordingly the supreme administration establishes this method as a strategy for and that applying the same is the responsibility of all administrative levels to guarantee its efficiency and success.

Results of phrases number $(1 / 1,1 / 2,1 / 3,1 / 5,1 / 6)$ indicated agreement of responses of both research groups at percentage ranged (66.67: $91.67 \%$ ) for supreme and middle administration and between (41.38: 81.03 \%) for execution administration of supreme administration concern of efficient participation of all departments in permanent improvement operations, on having an improvement plan.

Ayten Mahmoud Elmargoushy (2008) indicates that permanent development is the responsibility of administration and employees focusing on developing all the organization's activities and operations (5: 130).

Study of Maher Mohsen (2014) (1.) recommends the importance of compiling an improvement operations' budget.

From results of phrases number $(1 / 7 / 1,1 / 8,1 / 9 / 1,1 / 9 / 2)$ it is clear that there is an agreement by all responses of the two groups on holding cultural courses to Kaizen's importance, providing support and training to the directorate's employees.

This agrees with results of study of Sherihan Yehia Moursy (2017) ( ${ }^{2} 2$ ) confirming a gap between supreme administration and sports specialists of the directorate in participation in decision making process.

Also and from phrases number $(1 / 10,1 / 11,1 / 12,1 / 13,1 / 14,1 / 15,1 / 16)$ it is clear that the research sample agree at percentage between (66.67: $91.67 \%$ ) for supreme and middle administration and at (41.38: $89.66 \%$ ) for executive management provided all data and facts are available for administrative decision making, availing new evaluation methods to avoid error repetition.

Study of Dalia Taha Mahmoud Youssef (2013) (7) recommends the importance of correcting errors upon occurrence and focusing on permanent improvement.

But phrases number $(1 / 8 / 1,1 / 18 / 2,1 / 18 / 3,1 / 18 / 4)$ indicating employees participation in selecting operation required to be improved, looking for new methods of operations 
improvement, supreme and middle administration's agreement ranged between (66.67 : 91.67 $\%)$ and agreement percentage (37.93: $72.41 \%)$ for executive administration.

Ahmed Abdelsalam (2016), Nagy Ismail, Mohamed Ibrahim Meghawry (2014) indicated the importance of participating in administrating and formulating change plans for operations required to be improved ( $1: 8),(1 \leq: 114)$

The researcher indicates the importance of all administrative levels participation in planning to carry out operations of improvement.

\section{Table (6) Results of Repetition Percentage, Chi square Distribution and Outweighed Percentage for Response in the Second Factor:}

Procedures Steps of Kaizen's Methodology - First Dimension: Planning

\begin{tabular}{|c|c|c|c|c|c|c|c|c|c|c|}
\hline \multirow[t]{3}{*}{ Serial } & \multirow[t]{3}{*}{ Phrase content } & \multicolumn{4}{|c|}{$\begin{array}{l}\text { Supreme and middle } \\
\text { administration } \\
\mathrm{N}=12\end{array}$} & \multicolumn{4}{|c|}{$\begin{array}{l}\text { Supreme and middle } \\
\text { administration } \\
\mathrm{N}=\mathbf{5 8}\end{array}$} & \multirow{3}{*}{$\begin{array}{l}\text { Chi square } \\
\text { Distribution }\end{array}$} \\
\hline & & \multicolumn{2}{|c|}{ Agreeing } & \multicolumn{2}{|c|}{ Disagreeing } & \multicolumn{2}{|c|}{ Agreeing } & \multicolumn{2}{|c|}{ Disagreeing } & \\
\hline & & $\mathrm{C}$ & $\%$ & $\mathrm{C}$ & $\%$ & $\mathrm{C}$ & $\%$ & $\mathrm{C}$ & $\%$ & \\
\hline \multicolumn{11}{|l|}{2} \\
\hline $2 / 1$ & $\begin{array}{l}\text { Ordering all problems facing } \\
\text { the directorate according to } \\
\text { priority }\end{array}$ & 11 & 91.67 & 1 & 8.33 & 53 & 91.38 & 5 & 8.62 & 0.001 \\
\hline $2 / 2$ & $\begin{array}{c}\text { Collecting data and } \\
\text { information about all } \\
\text { problems and verifying real } \\
\text { causes }\end{array}$ & 10 & 83.33 & 2 & 16.67 & 44 & 75.86 & 14 & 24.14 & 0.315 \\
\hline $2 / 3$ & $\begin{array}{l}\text { Identifying causes resulted } \\
\text { in such problems }\end{array}$ & 10 & 83.33 & 2 & 16.67 & 46 & 79.31 & 12 & 20.69 & 0.101 \\
\hline $2 / 4$ & $\begin{array}{l}\text { Selecting the most critical } \\
\text { problems to be solved }\end{array}$ & 11 & 91.67 & 1 & 8.33 & 51 & 87.93 & 7 & 12.07 & 0.137 \\
\hline $2 / 5$ & $\begin{array}{l}\text { Clarifying the main problems } \\
\text { causes after separating the } \\
\text { real cause from the } \\
\text { secondary ones }\end{array}$ & 11 & 91.67 & 1 & 8.33 & 50 & 86.21 & 8 & 13.79 & 0.265 \\
\hline $2 / 6$ & $\begin{array}{l}\text { Suggesting different ideas } \\
\text { for solving such problem }\end{array}$ & 10 & 83.33 & 2 & 16.67 & 42 & 72.41 & 16 & 27.59 & 0.621 \\
\hline $2 / 7$ & $\begin{array}{c}\text { Estimating period required } \\
\text { to solve this problem }\end{array}$ & 10 & 83.33 & 2 & 16.67 & 22 & 37.93 & 36 & 62.07 & $* 8.259$ \\
\hline $2 / 8$ & $\begin{array}{l}\text { Establishing an improvement } \\
\text { plan }\end{array}$ & 11 & 91.67 & 1 & 8.33 & 49 & 84.48 & 9 & 15.52 & 0.419 \\
\hline $2 / 9$ & $\begin{array}{l}\text { Coordinating between all the } \\
\text { directorate's departments to } \\
\text { execute improvement plans } \\
\text { efficiently }\end{array}$ & 11 & 91.67 & 1 & 8.33 & 43 & 74.14 & 15 & 25.86 & 1.733 \\
\hline
\end{tabular}

Chi square Distribution (0.05.2) $=5.991$

From table number (6) of the second factor - first dimension: Planning, no differences between responses of the research sample groups about phrases of the first dimensions as Chi square Distribution was less than its tabular value at level (0.05) and ranged between (0.001: 1.733) except for phrase number (2/7) as (Ca2) value reached (8.259).

Results of phrases number $(2 / 1,2 / 2,2 / 3,2 / 4,2 / 5,2 / 6,2 / 7,2 / 8,2 / 9)$ indicated responses of the two researched groups at percentage $(83.33: 91.67 \%)$ for supreme and middle administration 
and between (72.41 : $91.38 \%$ ) for executive administration provided youth and sports directorate plans, collect data and information of all problems, selecting the most important problem, clarifying the main problem causes and suggesting problems solution.

Ahmed Abdelsalam (2016) indicates that: Analyzing the organization's environment and analyzing available internal potentials may affect suitable strategy determination $(1: 36,37)$

Table (7) Results of Repetition Percentage, Chi square Distribution and Outweighed Percentage for Response in the Second Factor:

\section{Procedures Steps of Kaizen's Methodology - Second Dimension: Execution}

\begin{tabular}{|c|c|c|c|c|c|c|c|c|c|c|}
\hline \multirow[t]{3}{*}{ Serial } & \multirow[t]{3}{*}{ Phrase content } & \multicolumn{4}{|c|}{$\begin{array}{l}\text { Supreme and middle } \\
\text { administration } \\
\mathrm{N}=12\end{array}$} & \multicolumn{4}{|c|}{$\begin{array}{c}\text { Supreme and middle } \\
\text { administration } \\
\mathrm{N}=\mathbf{5 8}\end{array}$} & \multirow{3}{*}{$\begin{array}{l}\text { Chi square } \\
\text { Distribution }\end{array}$} \\
\hline & & \multicolumn{2}{|c|}{ Agreeing } & \multicolumn{2}{|c|}{ Disagreeing } & \multicolumn{2}{|c|}{ Agreeing } & \multicolumn{2}{|c|}{ Disagreeing } & \\
\hline & & $\mathrm{C}$ & $\%$ & $\mathrm{C}$ & $\%$ & $\mathrm{C}$ & $\%$ & $\mathrm{C}$ & $\%$ & \\
\hline \multicolumn{11}{|l|}{3} \\
\hline $3 / 1$ & \begin{tabular}{l}
\multicolumn{1}{c}{ Designing a } \\
specialized unit for \\
permanent review \\
and evaluation
\end{tabular} & 4 & 33.33 & 8 & 66.67 & 13 & 22.41 & 45 & 77.59 & 0.645 \\
\hline $3 / 2$ & $\begin{array}{l}\text { Executing changes } \\
\text { needed for solving } \\
\text { problems gradually }\end{array}$ & 9 & 75.00 & 3 & 25.00 & 42 & 72.41 & 16 & 27.59 & 0.034 \\
\hline $3 / 3$ & $\begin{array}{l}\text { Availing logistic } \\
\text { materials "appliances } \\
\text { and tools" needed for } \\
\text { plans execution }\end{array}$ & 8 & 66.67 & 4 & 33.33 & 35 & 60.34 & 23 & 39.66 & 0.168 \\
\hline $3 / 4$ & $\begin{array}{c}\text { Training and } \\
\text { qualifying assigned } \\
\text { employees to execute } \\
\text { suggested plans }\end{array}$ & 5 & 41.67 & 7 & 58.33 & 21 & 36.21 & 37 & 63.79 & 0.127 \\
\hline $3 / 5$ & $\begin{array}{l}\text { Executing determined } \\
\text { corrective procedures }\end{array}$ & 7 & 58.33 & 5 & 41.67 & 31 & 53.45 & 27 & 46.55 & 0.096 \\
\hline $3 / 6$ & $\begin{array}{l}\text { Collecting information } \\
\text { to identify corrective } \\
\text { procedures efficiency }\end{array}$ & 7 & 58.33 & 5 & 41.67 & 30 & 51.72 & 28 & 48.28 & 0.174 \\
\hline $3 / 7$ & $\begin{array}{l}\text { Observing the plan } \\
\text { execution time frame }\end{array}$ & 8 & 66.67 & 4 & 33.33 & 25 & 43.10 & 33 & 56.90 & 2.215 \\
\hline
\end{tabular}

Chi square Distribution (0.05.2) $=5.991$

It is clear from table number (7) of the second factor - second dimension: Execution, there are no significant differences between the two research sample groups about phrases of the second dimension as Chi square Distribution was less than its tabular value at level (0.05) and ranged between $(0.034: 2.215)$.

And the results of phrases number $(3 / 2,3 / 3,3 / 5,3 / 6,3 / 7)$ indicated agreement of the two research responses at percentage (58.33: $75.00 \%$ ) for supreme and middle administration and at (43.10 : $72.41 \%)$ for executive administration provided the supreme administration executes and develops works gradually, availing logistic resources needed for plans execution. 
Hassan Ahmed Elshafaey (2018) indicated the importance of availing logistic resources to satisfy the organization's main functions ( $\mathrm{V}: 28)$

For phrases number $(3 / 1,3 / 4)$ it was clear that the two research groups responses agreed at (33.33\%), (41.67\%) for the first group, and $(22.41 \%),(36.21 \%)$ for the second group successively upon that supreme administration shall design a unit for permanent review and evaluation.

Ahmed Elsherif (2018) clarifies that control and follow up is the means used by organizations to follow up business execution and development. ( $r: 45)$

Table (8) Results of Repetition Percentage, Chi square Distribution and Outweighed Percentage for Response in the Second Factor:

Procedures steps of Kaizen's Methodology - Third Dimension: Evaluation and Examination

\begin{tabular}{|c|c|c|c|c|c|c|c|c|c|c|}
\hline \multirow{3}{*}{ Serial } & \multirow{3}{*}{ Phrase content } & \multicolumn{4}{|c|}{$\begin{array}{l}\text { Supreme and middle } \\
\text { administration } \\
\qquad \mathrm{N}=12\end{array}$} & \multicolumn{4}{|c|}{$\begin{array}{l}\text { Supreme and middle } \\
\text { administration } \\
\qquad \mathrm{N}=58\end{array}$} & \multirow{3}{*}{$\begin{array}{l}\text { Chi square } \\
\text { Distribution }\end{array}$} \\
\hline & & \multicolumn{2}{|c|}{ Agreeing } & \multicolumn{2}{|c|}{ Disagreeing } & \multicolumn{2}{|c|}{ Agreeing } & \multicolumn{2}{|c|}{ Disagreeing } & \\
\hline & & C & $\%$ & C & $\%$ & C & $\%$ & $C$ & $\%$ & \\
\hline 4 & & & & & & & & & & \\
\hline $4 / 1$ & $\begin{array}{l}\text { A specialized unit for } \\
\text { permanent review and } \\
\text { evaluation }\end{array}$ & 4 & 33.33 & 8 & 66.67 & 14 & 24.14 & 44 & 75.86 & 0.440 \\
\hline $4 / 2$ & $\begin{array}{c}\text { A clear performance } \\
\text { indicators to evaluate and } \\
\text { execute its plans }\end{array}$ & 8 & 66.67 & 4 & 33.33 & 27 & 46.55 & 31 & 53.45 & 1.609 \\
\hline $4 / 3$ & $\begin{array}{l}\text { Clear and written review } \\
\text { and evaluation system }\end{array}$ & 5 & 41.67 & 7 & 58.33 & 24 & 41.38 & 34 & 58.62 & 0.000 \\
\hline $4 / 4$ & $\begin{array}{l}\text { Profiting from feedback of } \\
\text { evaluation results to } \\
\text { improve its works }\end{array}$ & 10 & 83.33 & 2 & 16.67 & 38 & 65.52 & 20 & 34.48 & 1.464 \\
\hline $4 / 5$ & $\begin{array}{l}\text { Comparing data before } \\
\text { and after corrective } \\
\text { procedures }\end{array}$ & 8 & 66.67 & 4 & 33.33 & 20 & 34.48 & 38 & 65.52 & 4.291 \\
\hline $4 / 6$ & $\begin{array}{l}\text { Analyzing the gap } \\
\text { between the required } \\
\text { results and the actual } \\
\text { ones of the used } \\
\text { corrective procedures to } \\
\text { verify that new changes } \\
\text { work as planned }\end{array}$ & 9 & 75.00 & 3 & 25.00 & 22 & 37.93 & 36 & 62.07 & 5.537 \\
\hline
\end{tabular}




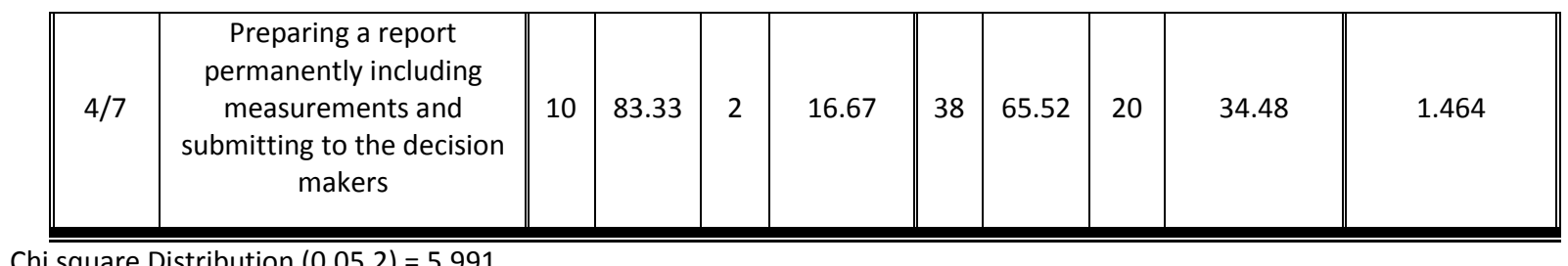

Chi square Distribution (0.05.2) $=5.991$

It is clear from table number (8) of the second factor - third dimension: evaluation and examination, there are no significant differences between the two research sample groups about phrases of the third dimension as Chi square Distribution was less than its tabular value at level (0.05) and ranged between (0.000: 5.537).

And the results of phrases number $(4 / 2,4 / 4,4 / 5,4 / 6,4 / 7)$ indicated agreement of the two research responses at percentage (66.67: $83.33 \%$ ) for supreme and middle administration and at (65.52 : $34.48 \%)$ for executive administration subject to evaluating permanent improvement of performance of youth and sports directorate via a clear performance indicators, profiting from feedback of evaluation results, analyzing the group between the requited results and the actual ones of the used corrective procedures.

Ismail Abdelfattah (2019): indicates that follow up and evaluation is a function focusing on measuring and correcting means of performance, deviations and errors. ( $9: 133$ )

Also results of study of Dalia Taha Mahmoud (2013) (") focus on improving work circumstances and correcting errors upon occurrence.

For phrases number $(4 / 1,4 / 2)$ both research groups agreed by a law percentage reached (33.33 $\%),(41.67 \%)$ "supreme and idle administration", and (24.14 \%), (41.38\%) "executive administration" respectively that evaluating permanent improvement at the directorate through a specialized unit for permanent review and evaluation.

Study of Riham Mohamed Aly (2019) (19) recommends the importance of applying control and follow system to performance on a regular basis.

The researcher considers evaluation and examination as one of the most important administrative functions as it identifies the gaps between results required to be achieved and what was reached and how far the director's sports specialists can fulfill their tasks.

Table (9) Results of Repetition Percentage, Chi square Distribution and Outweighed Percentage for Response in the Second Factor:

\section{Procedures steps of Kaizen's Methodology - Fourth Dimension: Response to Suggested Improvements}

\begin{tabular}{|c|c|c|c|c|c|c|}
\hline \multirow[t]{2}{*}{ Serial } & \multirow[t]{2}{*}{ Phrase content } & \multicolumn{2}{|c|}{$\begin{array}{l}\text { Supreme and middle } \\
\text { administration } \\
\qquad \mathrm{N}=12\end{array}$} & \multicolumn{2}{|c|}{$\begin{array}{l}\text { Supreme and middle } \\
\text { administration } \\
\qquad \mathrm{N}=58\end{array}$} & \\
\hline & & Agreeing & Disagreeing & Agreeing & Disagreeing & Chi square \\
\hline
\end{tabular}




\begin{tabular}{|c|c|c|c|c|c|c|c|c|c|c|}
\hline & & $C$ & $\%$ & C & $\%$ & $C$ & $\%$ & $\mathrm{C}$ & $\%$ & Distribution \\
\hline \multicolumn{11}{|l|}{ 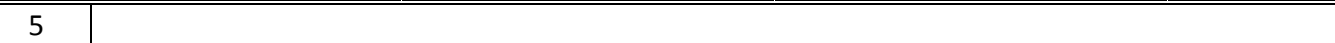 } \\
\hline $5 / 1$ & $\begin{array}{l}\text { Adopting changes } \\
\text { that achieved the } \\
\text { require results }\end{array}$ & 11 & 91.67 & 1 & 8.33 & 47 & 81.03 & 11 & 18.97 & 0.791 \\
\hline $5 / 2$ & $\begin{array}{l}\text { Taking necessary } \\
\text { procedures to } \\
\text { execute these } \\
\text { changes }\end{array}$ & 11 & 91.67 & 1 & 8.33 & 43 & 74.14 & 15 & 25.86 & 1.733 \\
\hline $5 / 3$ & $\begin{array}{c}\text { Establishing norms } \\
\text { changes }\end{array}$ & 10 & 83.33 & 2 & 16.67 & 31 & 53.45 & 27 & 46.55 & 3.660 \\
\hline $5 / 4$ & $\begin{array}{l}\text { Training employees } \\
\text { of youth and sports } \\
\text { directorate on } \\
\text { executing required } \\
\text { changes }\end{array}$ & 8 & 66.67 & 4 & 33.33 & 20 & 34.48 & 38 & 65.52 & 4.291 \\
\hline $5 / 5$ & $\begin{array}{l}\text { Correcting deviations } \\
\text { of non conformity } \\
\text { with the approved } \\
\text { performance } \\
\text { indicators }\end{array}$ & 9 & 75.00 & 3 & 25.00 & 37 & 63.79 & 21 & 36.21 & 0.554 \\
\hline $5 / 6$ & $\begin{array}{l}\text { Profiting from } \\
\text { developing } \\
\text { information } \\
\text { technology and new } \\
\text { communication } \\
\text { related to the } \\
\text { directorate's } \\
\text { business }\end{array}$ & 11 & 91.67 & 1 & 8.33 & 49 & 84.48 & 9 & 15.52 & 0.419 \\
\hline
\end{tabular}

Chi square Distribution (0.05.2) $=5.991$

It is clear from table number (9) of the second factor - forth dimension: response to improvements, there are no significant differences between the two research sample groups about phrases of the third dimension as Chi square Distribution was less than its tabular value at level (0.05) and ranged between (0.419: 4.291).

From results of phrases number $(5 / 1,5 / 2,5 / 3,5 / 4,5 / 5,5 / 6)$ it is clear that all groups' responses were that youth and sports directorate shall respond to the suggested improvements via adopting changes that achieved the required results, taking suitable procedures to achieve these changes, training employees on executing required changes, profiting from information technology and communication development at percentage (66.67 : $91.76 \%$ )for supreme and middle administration and (34.48: $84.48 \%)$ for executive administration.

Ahmed Abdelsalam Mousa (2016) clarified the importance of execution agrees with what was determined. ( $:$ :37)

The researcher believes that after evaluation and examination, the last step related to 
responding to suggested improvements arises, according to Kaizen's methodological procedures.

Table (10) results of repetition percentage, Chi square Distribution and outweighed percentage for response in the third factor: Effects of Using (Kaizen) Methodology to Improve

Permanent Performance of Achieve Excellent Organizational Performance at Youth and Sports Directorate in Alexandria - First Dimension: Improving Employees' Performance at Youth and Sports Directorate

\begin{tabular}{|c|c|c|c|c|c|c|c|c|c|c|}
\hline \multirow[t]{3}{*}{ Serial } & \multirow[t]{3}{*}{ Phrase content } & \multicolumn{4}{|c|}{$\begin{array}{l}\text { Supreme and middle } \\
\text { administration } \\
\mathrm{N}=12\end{array}$} & \multicolumn{4}{|c|}{$\begin{array}{c}\text { Supreme and middle } \\
\text { administration } \\
\mathrm{N}=\mathbf{5 8}\end{array}$} & \multirow{3}{*}{$\begin{array}{l}\text { Chi square } \\
\text { Distribution }\end{array}$} \\
\hline & & \multicolumn{2}{|c|}{ Agreeing } & \multicolumn{2}{|c|}{ Disagreeing } & \multicolumn{2}{|c|}{ Agreeing } & \multicolumn{2}{|c|}{ Disagreeing } & \\
\hline & & $\mathrm{C}$ & $\%$ & C & $\%$ & $\mathrm{C}$ & $\%$ & $\mathrm{C}$ & $\%$ & \\
\hline \multicolumn{11}{|l|}{6} \\
\hline $6 / 1$ & $\begin{array}{l}\text { Developing their } \\
\text { abilities to adapt with } \\
\text { changes and new } \\
\text { circumstances }\end{array}$ & 9 & 75.00 & 3 & 25.00 & 39 & 67.24 & 19 & 32.76 & 0.278 \\
\hline $6 / 2$ & $\begin{array}{l}\text { Changing the } \\
\text { directorate's } \\
\text { employees culture } \\
\text { through training and } \\
\text { learning }\end{array}$ & 9 & 75.00 & 3 & 25.00 & 27 & 46.55 & 31 & 53.45 & 3.221 \\
\hline $6 / 3$ & $\begin{array}{l}\text { Discovering new } \\
\text { creative potentials } \\
\text { inconformity with } \\
\text { acting according to } \\
\text { different situations } \\
\end{array}$ & 10 & 83.33 & 2 & 16.67 & 45 & 77.59 & 13 & 22.41 & 0.195 \\
\hline $6 / 4$ & $\begin{array}{l}\text { Developing employees' } \\
\text { experiences, efficiency } \\
\text { and potentials for } \\
\text { solving problems }\end{array}$ & 10 & 83.33 & 2 & 16.67 & 49 & 84.48 & 9 & 15.52 & 0.010 \\
\hline $6 / 5$ & $\begin{array}{l}\text { Enabling and } \\
\text { motivating the } \\
\text { directorate's } \\
\text { employees } \\
\end{array}$ & 9 & 75.00 & 3 & 25.00 & 41 & 70.69 & 17 & 29.31 & 0.091 \\
\hline $6 / 6$ & $\begin{array}{l}\text { Appreciating and } \\
\text { awarding creative } \\
\text { employees }\end{array}$ & 11 & 91.67 & 1 & 8.33 & 30 & 51.72 & 28 & 48.28 & $* 6.537$ \\
\hline $6 / 7$ & $\begin{array}{c}\text { Preparing a leading } \\
\text { environment } \\
\text { interactive with results } \\
\text { desiring to make } \\
\text { change }\end{array}$ & 10 & 83.33 & 2 & 16.67 & 28 & 48.28 & 30 & 51.72 & 4.924 \\
\hline $6 / 8$ & $\begin{array}{c}\text { Reducing differences } \\
\text { between } \\
\text { administrative levels at } \\
\text { youth and sports } \\
\text { directorate }\end{array}$ & 9 & 75.00 & 3 & 25.00 & 19 & 32.76 & 39 & 67.24 & $* 8.392$ \\
\hline $6 / 9$ & $\begin{array}{l}\text { Depending on group } \\
\text { work "team work" }\end{array}$ & 9 & 75.00 & 3 & 25.00 & 23 & 39.66 & 35 & 60.34 & 5.005 \\
\hline
\end{tabular}

Chi square Distribution (0.05.2) $=5.991$

It is clear from table number (10) of the third factor - first dimension: improving employees' performance, there are no significant differences between the two research sample groups about phrases of the third dimension as Chi square Distribution was less than its tabular value 
at level $(0.05)$ and ranged between $(0.010: 4.924)$ except for phrases number $(6 / 6,6 / 8)$.

Results of phrases number $(6 / 1,6 / 2,6 / 3,6 / 4,6 / 5,6 / 7,6 / 9)$ indicated agreement of the two research groups between ( $75.00: 83.33 \%$ ) for supreme and middle administration and (39.66 : $84.48 \%)$ for executive administration to indicate dependence on group work, preparing on interactive leading environment assisting in applying Kaizen's methodology to improving employees performance.

This agrees with results of study of Mohamed Gabr Elgharawy (2019) (1 ${ }^{r}$ ) indicating the importance or training courses to develop knowledge and skills related to and developing function.

Hassan Ahmed Elshafaey (2018) confirms the importance of adopting methods and behaviors enabling employees to authorizing behaviors and enhancing inferiors' potentials. $(\vee: 83)$

But for phrases number $(6 / 6,6 / 8)$ they are the most contrasted ones as supreme and supervisors administration agreed at (91.67\%), (75.00 \%) respectively on the applying Kaizen's methodology improves employees performance via appreciating and awarding creative employees, reducing difference between administrative levels while executive administration's response reached (51.72\%), (32. $67 \%)$.

Opinions of executive administration agree with study of Sherihan Yehia Moursy (2017) (21) Rihab Aly Amin, Riham Amin Hamza (2015) (16) that creative employees receive neither incentives nor awards contributing to job satisfaction.

Hoda Omar Abdalla (2018) confirms that incentives motivate employees. (^: 47)

Riham Amin Hamza (2010) (17) recommends providing training courses to sports specialists and sports field leaderships.

Table (11) Results of Repetition Percentage, Chi square Distribution and Outweighed Percentage for Response in the Third Factor: Effects of Using (Kaizen) Methodology to Improve Permanent Performance of Achieve Excellent Organizational Performance at Youth and Sports Directorate in Alexandria - Second Dimension: Improving Operations Performance

\begin{tabular}{|c|c|c|c|c|c|c|c|c|c|c|}
\hline \multirow{3}{*}{ Serial } & \multirow{3}{*}{ Phrase content } & \multicolumn{4}{|c|}{$\begin{array}{l}\text { Supreme and middle } \\
\text { administration } \\
\qquad N=12\end{array}$} & \multicolumn{4}{|c|}{$\begin{array}{l}\text { Supreme and middle } \\
\text { administration } \\
\qquad N=58\end{array}$} & \multirow{3}{*}{$\begin{array}{l}\text { Chi square } \\
\text { Distribution }\end{array}$} \\
\hline & & \multicolumn{2}{|c|}{ Agreeing } & \multicolumn{2}{|c|}{ Disagreeing } & \multicolumn{2}{|c|}{ Agreeing } & \multicolumn{2}{|c|}{ Disagreeing } & \\
\hline & & C & $\%$ & $\mathrm{C}$ & $\%$ & $C$ & $\%$ & C & $\%$ & \\
\hline \multicolumn{11}{|l|}{7} \\
\hline $7 / 1$ & $\begin{array}{c}\text { Focusing on } \\
\text { improving work } \\
\text { climate or } \\
\text { environment and any } \\
\text { factors supporting } \\
\text { change operations }\end{array}$ & 9 & 75.00 & 3 & 250.00 & 24 & 41.38 & 34 & 58.62 & 4.510 \\
\hline
\end{tabular}




\begin{tabular}{|c|c|c|c|c|c|c|c|c|c|c|}
\hline $7 / 2$ & $\begin{array}{l}\text { Identifying factors } \\
\text { supporting change } \\
\text { operations }\end{array}$ & 11 & 91.67 & 1 & 8.33 & 31 & 35.45 & 27 & 46.55 & $* 6.051$ \\
\hline \multicolumn{11}{|l|}{$7 / 3$} \\
\hline $7 / 3 / 1$ & Financial resources & 11 & 91.67 & 1 & 8.33 & 52 & 89.66 & 6 & 10.34 & 0.045 \\
\hline $7 / 3 / 2$ & Substantial potentials & 11 & 91.67 & 1 & 8.33 & 49 & 84.48 & 9 & 15.52 & 0.0419 \\
\hline $7 / 3 / 3$ & Time & 10 & 83.33 & 2 & 16.67 & 21 & 36.21 & 37 & 63.79 & $* 8.950$ \\
\hline $7 / 3 / 4$ & Operating operations & 10 & 83.33 & 2 & 16.67 & 18 & 31.03 & 40 & 68.97 & *11.331 \\
\hline \multicolumn{11}{|l|}{$7 / 4$} \\
\hline $7 / 4 / 1$ & Substantial potentials & 11 & 91.67 & 1 & 8.33 & 49 & 84.48 & 9 & 15.52 & 0.419 \\
\hline $7 / 4 / 2$ & Human potentials & 11 & 91.67 & 1 & 8.33 & 42 & 72.41 & 16 & 27.59 & 2.004 \\
\hline $7 / 4 / 3$ & Financial resources & 10 & 83.33 & 2 & 16.67 & 44 & 75.86 & 14 & 24.14 & 0.315 \\
\hline $7 / 5$ & $\begin{array}{c}\text { Identifying } \\
\text { restrictions of } \\
\text { executing quality } \\
\text { norms of every } \\
\text { department of youth } \\
\text { and sports } \\
\text { directorate }\end{array}$ & 9 & 75.00 & 3 & 25.00 & 32 & 55.71 & 26 & 44.83 & 1.611 \\
\hline $7 / 6$ & $\begin{array}{l}\text { Identifying tasks for } \\
\text { employees to be } \\
\text { trained on inside } \\
\text { every directorate's } \\
\text { department }\end{array}$ & 9 & 75.00 & 3 & 25.00 & 26 & 44.83 & 32 & 55.17 & 3.621 \\
\hline $7 / 7$ & $\begin{array}{c}\text { Creating new work } \\
\text { mechanisms }\end{array}$ & 8 & 66.67 & 4 & 33.33 & 22 & 37.93 & 36 & 62.07 & 3.352 \\
\hline $7 / 8$ & $\begin{array}{l}\text { Clarifying work } \\
\text { procedures for all } \\
\text { youth and sports } \\
\text { directorate's } \\
\text { employees }\end{array}$ & 11 & 91.67 & 1 & 8.33 & 47 & 81.03 & 11 & 18.97 & 0.791 \\
\hline
\end{tabular}

Chi square Distribution (0.05.2) $=5.991$

It is clear from table number (11) of the third factor - second dimension: improving performance of operations, there are no significant differences between the two research samples groups about phrases of the second dimension as Chi square Distribution was less than its tabular value at level $(0.05)$ and ranged between $(0.315: 4.510)$ except for phrases number $(7 / 2,7 / 3 / 3,7 / 3 / 4)$ as ( $\mathrm{Ca} 2)$ value exceeded its tabular value and ranged between (6.051 : 11.331).

For phrases number $(7 / 2,7 / 3 / 3,7 / 3 / 4)$ they are the most contrasted ones in responses of the research groups as while supreme and supervisory administrations agreed at (83.33: 91.67 \%) upon that applying Kaizen's methodology improves operations performance via identifying factors supporting change, identifying aspects of waste inside, we find that executive management achieved a percentage from 
(31.03: $53.45 \%)$.

This agreed with results of study of Riham mohamed Aly (2019 (19) indicating the increase of communication efficiency between individuals and units through coordination and integration of works between them and quick obtainment of data and information to provide services and overcome waste.

Also from results of phrases numbers $(7 / 1,7 / 3 / 1,7 / 3 / 2,7 / 4 / 1,7 / 4 / 2,7 / 4 / 3,7 / 5,7 / 6,7 / 7,7 / 8)$ it is clear that there is an agreement between most of groups response that applying Kaizen's methodology improves operations performance by focusing on improving work environment, identifying waste aspects, identifying needs of all directorate's departments of substantial and human potentials, identifying quality norms execution barriers, and crating new work mechanisms at (66.67 : $91.76 \%$ ) for supreme and middle administration and (37.93: $89.66 \%$ ) for executive administration.

This agrees with results of Dalia Taha Mahmoud Youssef (2013) (7) of that using Kaizen's method requires not only new financial resources but the best use of the organization's assets.

Table (12) Results of Repetition Percentage, Chi square Distribution and Outweighed

Percentage for Response in the Third Factor: Effects of Using (Kaizen) Methodology to Improve Permanent Performance of Achieve Excellent Organizational Performance at Youth and Sports Directorate in Alexandria - Third Dimension: Improving Performance of Youth and Sports Directorates Performance in Alexandria

\begin{tabular}{|c|c|c|c|c|c|c|c|c|c|c|}
\hline \multirow[t]{3}{*}{ Serial } & \multirow[t]{3}{*}{ Phrase content } & \multicolumn{4}{|c|}{$\begin{array}{l}\text { Supreme and middle } \\
\text { administration } \\
\mathrm{N}=12\end{array}$} & \multicolumn{4}{|c|}{$\begin{array}{l}\text { Supreme and middle } \\
\text { administration } \\
\mathrm{N}=\mathbf{5 8}\end{array}$} & \multirow{3}{*}{$\begin{array}{c}\text { Chi square } \\
\text { Distribution }\end{array}$} \\
\hline & & \multicolumn{2}{|c|}{ Agreeing } & \multicolumn{2}{|c|}{ Disagreeing } & \multicolumn{2}{|c|}{ Agreeing } & \multicolumn{2}{|c|}{ Disagreeing } & \\
\hline & & $\mathrm{C}$ & $\%$ & $\mathrm{C}$ & $\%$ & $\mathrm{C}$ & $\%$ & $\mathrm{C}$ & $\%$ & \\
\hline 8 & \multicolumn{10}{|c|}{ Youth and sports directorate is able to: } \\
\hline $8 / 1$ & $\begin{array}{l}\text { Consolidating good } \\
\text { means and norms of } \\
\text { work procedures inside } \\
\text { the directorate with } \\
\text { following international } \\
\text { norms }\end{array}$ & 8 & 66.67 & 4 & 33.33 & 24 & 41.38 & 34 & 58.62 & 2.562 \\
\hline $8 / 2$ & \multicolumn{10}{|c|}{ Responding effectively to variable: } \\
\hline $8 / 2 / 1$ & Internally & 10 & 83.33 & 2 & 16.67 & 48 & 82.76 & 10 & 17.24 & 0.002 \\
\hline $8 / 2 / 2$ & Externally & 11 & 91.67 & 1 & 8.33 & 47 & 81.03 & 11 & 18.97 & 0.791 \\
\hline $8 / 3$ & $\begin{array}{l}\text { Expecting beneficiaries } \\
\text { desires and } \\
\text { requirements through: }\end{array}$ & & & & & & & & & \\
\hline $8 / 3 / 1$ & Questionnaire from & 7 & 58.33 & 5 & 41.67 & 15 & 25.86 & 43 & 74.14 & 4.865 \\
\hline $8 / 3 / 2$ & Social media & 11 & 91.67 & 1 & 8.33 & 52 & 89.66 & 6 & 10.34 & 0.045 \\
\hline $8 / 3 / 3$ & $\begin{array}{c}\text { Complaints and } \\
\text { suggestions boxes }\end{array}$ & 10 & 83.33 & 2 & 16.67 & 43 & 74.14 & 15 & 25.86 & 0.457 \\
\hline $8 / 3 / 4$ & Interviews & 9 & 75.00 & 3 & 25.00 & 20 & 34.48 & 38 & 65.52 & $* 6.727$ \\
\hline $8 / 4$ & $\begin{array}{l}\text { Developing youth and } \\
\text { sports directorates } \\
\text { competitiveness }\end{array}$ & 10 & 83.33 & 2 & 16.67 & 47 & 81.03 & 11 & 18.97 & 0.035 \\
\hline $8 / 5$ & $\begin{array}{l}\text { Using permanent } \\
\text { improvement tools } \\
\text { efficiently }\end{array}$ & 8 & 66.67 & 4 & 33.33 & 21 & 36.21 & 37 & 63.79 & 3.802 \\
\hline
\end{tabular}


Chi square Distribution $(0.05 .2)=5.991$

It is clear from table number (12) of the third factor - third dimension: improving the directorate's performance, there are no a statistical significant differences between the two research sample groups about phrases of the second dimension as Chi square Distribution was less than its tabular value at level (0.05) and ranged between (0.002: 4.865) except for phrases number (8/3/4) as (Ca 2) value was (6.727).

Results of phrases numbers $(8 / 1,8 / 2 / 1,8 / 2 / 2,8 / 3 / 1,8 / 3 / 2,8 / 3 / 3,8 / 4,8 / 5)$ indicated agreement of all the two types responses at (66.67 : $91.76 \%)$ for supreme and middle administration at (37.93 : $89.66 \%$ ) for executive administration that youth and sports directorate is able to consolidate good methods and norms of work procedures inside the directorate, efficient response to variables in both internal and external environment, expect beneficiaries desires, increasing youth and sports directorate's competiveness, using permanent improvement tools efficiently.

Results of study of Walid Abdelhafiz (2014) (24), Aiman Abdelhamid (2013) ( $\{$ ), confirm that using information technology in administrating organizations according to beneficiary's needs develops the organization's efficiency.

Also study of Riham Amin Hamza (2017) (18) recommends the importance of having a database contributing to improvement operations.

But phrases number (8/3/4) contradictory research groups subjects responses are clear, as while supreme and supervisors administrations agreed at (75.00\%) upon that the directorate is able to expect beneficiaries desires, executive administration's opinions disapproved the same at $(34.48 \%)$.

Ahmed Mohamed Ghonim (2009) indicates establishing a database including information about beneficiaries expectations desires and identifying their tastes changes (3: 334).

The researcher believes that current international variables of the directorate's surrounding environment impose applying new scientific methods to administration to deal with such challenges and carrying out permanent improvement operations.

\section{Conclusions:}

- There are no culturing courses to convince all administrative levels employees with all advantages of applying Kaizen's methodology.

- Not constituting groups of employees "quality departments" to solve problems and reach new changes.

- Supreme administration of youth and sports directorate plans via ordering all problems facing the directorate according to priority.

- There are shortage in suggesting different ideas and suggestions to solve such problem and carry out a plan for the required improvements.

- None analyzing the gap between the required results and the actual results of the used corrective procedures to verify that new changes work as planned. 
- Weak response of youth and sports directorate to the suggested improvements and no suitable procedures are taken to execute changes.

- No waste aspects are determined inside every department of youth and sports directorate including wasting time, operation processes.

- Non effective response to variables of external and internal environment and non expecting beneficiaries' desires and requirements.

\section{Recommendation}

- Applying steps of permanent improvement, PDCA course inside youth and sports directorate as it is the means of permanent improvement by making a field study to know any dimensions needing actual application before other ones.

- Employees should be enabled to join cultural courses to know the importance of using Kaizen methodology.

- $\quad$ Focusing on permanent training of all employees as per occupational needs and measuring the training effects.

- Establishing a mechanism to motivate employees' creative efforts to encourage creation.

- Focusing on measuring beneficiaries desires and needs on a permanent basis as they are the key of change and development success at the directorate.

- There should be a unit inside the organizational structure to carry out permanent review and evaluation.

\section{Bibliography}

First: Arabic Bibliography

1 Ahmed Abdelsalam Mousa : Effects of Strategic Plan of Economic Entities on (2016) Marketing, First Print, Universities Publishing House, Cairo.

r Ahmed Elsherif (2018)

: Sports, Governance, International Direction of Sports Organization's Performance, Dar El Fekr El Araby, Cairo.

3 Ahmed Mohamed Ghonim : The Japanese Approach of Permanent Improvement and (2009) How Far Arab Organizations Profit from, Modern Library for Printing and Publishing.

\& Aiman Abdelhamid (2013) : An Executive Plan to Develop Administrative Performance, Youth and Sports Directorate, Sharkia Governorate under Requirements of Applying Norms of Quality of Sigma 6, Magazine of Faculty of Physical Education for Girls, Alexandria University.

- Ayten Mahmoud : Evaluating Organizational Performance in International Elmargoushy (2008) Public Organizations, Universities Publishing House, Cairo.

1 Dalia Taha Mahmoud : How to Use Gemba Kaizen's Method in Developing Youssef (2013) University Education in Egypt, a Research Published on Magazine of Arab Studies of Education and Psychology, Issue (35), Part (4), Egypt. 
$\checkmark$ Hassan Ahmed Elshafaey (2018)

$\wedge \quad$ Hoda Omar Abdalla (2018)

$9 \quad$ Ismail Abdelkafy (2019)

1. Maher Mohsen Marheg : Managing Integrated Quality as an Administrative (2014)

11 Moamen Sharafeldin (2012)

ir Mohamed Gabr Elgharawy : (2019)

\section{ir Nadia Abdelkhalik Ramadan : Bakr (2016)}

Is Nagy Ismail Mohamed Meghawry (2014)

15 Qusayr Bin Odeh (2020)

Manual of Organization, Organizational and Enablement Development Network, New Administration and its Theories in Physical Education, First Print, Sports World Organization, Alexandria.

Mechanism of Administrative Enablement, Faculty of Economics and Administration, King Souad University, Jeddah.

Strategy between Planning and Quality, Planning of Performance and Quality of Production, Dar El Araby, Cairo.

Development Approach, Permanent Improvement (Kaizen), Faculty of Economics, Tishreen University, Syria.

hhtps://www.researchgate.net/ publication/320840281

The Role of Administration by Operations in Improving Economic Organization's Performance, a Case Study, Nokawis Organization for Sighted, Unpublished Master Thesis, Faculty of Economic and Commercial and Managerial Science, Algeria.

Administrative Enablement and its Relationship to Occupational Satisfaction for Managers and Teachers of Physical Education, National Schools, Baghdad, Unpublished Master Thesis, Faculty of Physical for Girls, Alexandria University.

An Approach to Permanent Improvement (Kaizen) and its Effects on Organization's Performance by Applying to Egypt Electricity Holding Company, a Thesis Published on Arab Magazine for Administration, Volume (63), First Issue, Faculty of Commerce, El Azhar University.

Hamed, : Professional Administrator, First Print, New Book Center, Ibrahim Cairo.

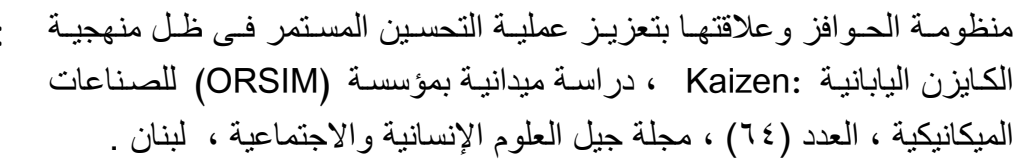

16 Rihab Aly Amin, Riham : The Relationship between Organizational Justice and Amin Hamza (2015) Specialist, Departments of Youth Care, Alexandria University, a Research Published on Faculty of Physical Education Magazine, Issue ( ), Volume ( ), Assiut University. 
17 Riham Amin Hamza (2015): : Contributions of Ministry of Youth and Sports to Achieve Permanent Development in Egypt, A Research Published on Faculty of Physical Education Magazine, Issue ( ), Volume ( ), Abo Kir - Alexandria University.

18 (2017)

19 Riham Mohamed Ibrahim (2019)

20 Rizan Salaheldin Ezzat, Berzin Sheikh Mohamed (2010)

r1 Sherihan Yehia (2017)

r2 (2017)

r3 Twaitia Eltaher (2017)

24 Walid Abdelhafiz (2014)

Second: Foreign references

Y5 Ann Bisou (2016)
Aly : A Suggested Model for Kaizen's Methodology (Permanent Improvement) to achieve Administrative Excellence, Faculty of Physical Education for Girls, Alexandria University, Unpublished Doctorate Thesis, Faculty of Physical Education for Girls, Alexandria University.

Developing Strategic Performance in Sports Clubs, a Research Published at Third International Scientific Conference, Sports and permanent Development, Faculty of Physical Education, Tanta University.

Method of Kaizen and its Relationship to Reduce Costs, a Research Published on Accounting and Financial Studies Magazine, Volume (5), Issue (10), Baghdad University.

Moursy : The Role of Administration by Enablement in Achieving Occupational Satisfaction for Employees of General Department of Youth Care, Tanta University, a Thesis Published at Third International Scientific Conference, Sports and Permanent Development, Faculty of Physical Education, Tanta University.

: Organizational Climate and its Relationship to Administrative Creation of Sports Specialist, Youth Directorates, Middle Delta Governorates, a Thesis Published at Third International Scientific Conference, Sports and Permanent Development, Faculty of Physical Education, Tanta University.

: Effects of Principles of Kaizen's Strategy in Activating the Clearer Production Technology, Case Study of Cement Company, El Maa El Abiad, Tibsa, Algeria, a Research Published on Economic Research Magazine, Volume (4), Issue (2), El Arabi Bin Mehidi University, Algeria.

: Six Sigma Method as a Suggested Model to Develop Administrative Work, youth care departments south valley and Aswan Universities, unpublished directorate thesis, Faculty of Physical Education, Asiut University.

Kaizen or How to Reach Your Goals Making Small Steps: Japanese Success Principles in Everyday Life, Amazon Digital Services LLC 
r6 Benjamin S Sweet (2015)

r7 Charles Protzman (2016)

r8 Glover et al., (2011)

r9 Kai Musashi (2016)

30 Masaaki Imai (2012)

r1 Richard Schonberger (2012)

r2 Robert Maurer (2012)
KAIZEN, the Pursuit of Continuous Improvement, Amazon Digital Services LLC

the Lean Practitioner's Field Book: Proven, Practical, Profitable and Powerful Techniques for Making Lean Really Work, Productivity Press

: A Case Study on Kaizen as a Learning Tool for a management Team. ناقص بيانات

Kaizen: How to Master Continuous Improvement and Transform Your Life One Step at a Time (Mindset, Kaizen, Continuous Improvement, Self Discipline), Amazon Digital Services LLC

Gemba Kaizen: A Commonsense Approach to a Continuous Improvement Strategy, McGraw-Hill Education; Second Edition

Best Practices in Lean Six Sigma Process Improvement: A Deeper Look, John Wiley \& Sons, Inc

The Spirit of Kaizen: Creating Lasting Excellence One Small Step at a Time, McGraw-Hill Education; 1 edition 